\title{
Chemoresistance of glioblastoma cancer stem cells - much more complex than expected
}

\author{
Dagmar Beier, Joerg B Schulz and Christoph P Beier
}

\begin{abstract}
Glioblastomas (GBM) are a paradigm for the investigation of cancer stem cells (CSC) in solid malignancies. The susceptibility of GBM CSC to standard chemotherapeutic drugs is controversial as the existing literature presents conflicting experimental data. Here, we summarize the experimental evidence on the resistance of GBM CSC to alkylating chemotherapeutic agents, with a special focus on temozolomide (TMZ). The data suggests that CSC are neither resistant nor susceptible to chemotherapy per se. Detoxifying proteins such as $\mathrm{O}^{6}$-methylguanine-DNAmethyltransferase (MGMT) confer a strong intrinsic resistance to CSC in all studies. Extrinsic factors may also contribute to the resistance of CSC to TMZ. These may include TMZ concentrations in the brain parenchyma, TMZ dosing schemes, hypoxic microenvironments, niche factors, and the re-acquisition of stem cell properties by nonstem cells. Thus, the interaction of CSC and chemotherapy is more complex than may be expected and it is necessary to consider these factors in order to overcome chemoresistance in the patient.
\end{abstract}

Keywords: glioblastoma, cancer stem cell, temozolomide, chemoresistance, BCNU

\section{Introduction}

The role of chemotherapy in the treatment of glioblastoma (GBM) has undergone considerable changes in the last two decades. While alkylating substances such as nimustine (ACNU), carmustine (BCNU), and lomustine (CCNU) have been used since the late 1970s [1,2], the introduction of temozolomide (TMZ) as standard treatment paved the way for a broader use of chemotherapy in the treatment of GBM $[3,4]$. TMZ, in addition to radiotherapy and surgical resection, improved both the overall survival and the progression-free survival in patients with newly diagnosed GBM [3]. Additionally, its low toxicity has led to TMZ being the first chemotherapeutic agent to be suitable for long-term application over several years, although debate continues on this issue $[5,6]$. Despite these efforts, the prognosis of patients suffering from GBM remains poor, with a median survival of only 14.6 months [3] and with few patients surviving longer than 5 years [7].

Cancer stem cells (CSC) are postulated mediators of chemoresistance. The CSC hypothesis proposes that tumors are driven by subpopulations of tumor cells with

\footnotetext{
* Correspondence: Christoph.Beier@gmx.de
Department of Neurology, RWTH Aachen, Medical School, Pauwelsstrasse 30,

* Correspondence: Christoph.Beier@gmx.de
Department of Neurology, RWTH Aachen, Medical School, Pauwelsstrasse 30, 52074 Aachen, Germany
}

(c) 2011 Beier et al; licensee BioMed Central Ltd. This is an Open Access article distributed under the terms of the Creative Commons Attribution License (http://creativecommons.org/licenses/by/2.0), which permits unrestricted use, distribution, and reproduction in any medium, provided the original work is properly cited. further postulates that CSC later differentiate into rapidly proliferating progenitor-like and more differentiated tumor cells that define the histological features of the tumor entity [8]. An important prediction of the CSC hypothesis is that CSC are more resistant towards radio- and chemotherapy than are rapidly proliferating progenitor cells and differentiated tumor cells. CSC survive intensive oncological therapies and then give rise to tumor recurrences [8].

GBM are a paradigm for the investigation of CSC in solid malignancies. The resistance of GBM CSC towards radiotherapy and chemotherapy has been extensively studied in the last 5 years. Here, we summarize the current knowledge on the resistance of GBM CSC to chemotherapy, with a special focus on TMZ as the current standard of care.

\section{Introduction - cancer stem cells}

For several types of brain tumors, including a subgroup of primary GBM, CSC were found to express CD133. $\mathrm{CD}_{133^{+}}$, but not $\mathrm{CD} 133^{-}$, tumor cells were able to reconstitute the initial tumor in vivo when injected into immune-deficient nude mice $[9,10]$. However, recent reports indicate that this initially proposed model may 
represent an oversimplification and stem cell-specificity of the epitope detected by the antibody AC133 (i.e. glycosylated prominin, CD133 [11]) has been questioned [12]. GBM cells may acquire CD133 after xenotransplanation [13], conversely $\mathrm{CD} 133^{+}$and $\mathrm{CD} 133^{-}$cells within CSC lines may have similar tumorigenic potential $[14,15]$. In addition, CD133 does not appear to be essential for stem cell-like properties, as subgroups of GBM driven by CD133- CSC have recently been identified [16-18]. Thus, stem cell-specific markers other than CD133 were sought for. In recent years new markers (e. g. CD15/SSEA-1, integrin $\alpha 6$ ) have been described, but there is no consensus on the optimal markers for CSC in GBM [18-21]. The CSC hypothesis states that tumor relapses are driven by CSC having escaped multimodal therapy. Possible explanations for treatment failure include insufficient drug delivery or the fact that the treatment targets only more differentiated tumor cells (the tumor bulk), while sparing the small subpopulation of CSC (e.g. via CSC specific mechanisms to escape chemotherapy-induced cell death) $[8,22,23]$. The CSC hypothesis further predicts that only therapies that efficiently eliminate the CSC fraction of a tumor are able to induce long-term responses and thereby halt tumor progression.

However, stem cell-specific therapies, although preventing further growth of the tumor, will not result in an impressive shrinkage of the lesion in vivo but in a persisting period of stable disease that may be followed by a late reduction of tumor volume [8]. Because CSC constitute only a rare subpopulation within a tumor, a therapeutic agent selectively depleting CSC will not substantially reduce the overall viability of tumor cells, but may efficiently inhibit their proliferation. In a clinical context, the CSC hypothesis challenges the classical oncological response criteria and questions the evaluation of therapeutic approaches by their effects on the tumor bulk [24].

In vitro, these implications raise questions about viability assays used to determine the survival of all tumor cells (e.g. metabolic assays like 3-(4,5-dimethylthiazole2-yl)-2,5-diphenyltetrazoliumbromide (MTT) or water soluble tetrazolium (WST), apoptosis/necrosis assays like terminal deoxynucleotidyl transferase dUTP nick end labeling (TUNEL) or propidium iodide). Such assays may fail to detect the stem cell-specific effects of a drug. Sequential in vivo transplantation experiments are the gold-standard to detect the small population of CSC within the whole of tumor cells [25]. Still, this experimental approach is only feasible to answer specific experimental questions but does not allow screening experiments. Several additional techniques that may help to better investigate the response of CSC to chemotherapy are currently evaluated (e.g. immediate testing of sorted tumor cells, treatment of tumor bearing mice, monitoring of DNA in CSC, mixed culture of CSC and cells without stem cell properties). At the moment, the combination of experiments investigating clonogenicity, stem cell marker expression, and differentiation of tumor cells may constitute a feasible set of screening experiments for stem cell toxicity in vitro (summarized in [12]). Recently described new cell culture methods that might help to avoid the above mentioned time-consuming experimental approaches remain controversial and require further scientific evaluation [26,27].

\section{Introduction - alkylating agents and DNA repair}

To date, two groups of alkylating agents are commonly used in the clinic: TMZ (8-Carbamoyl-3-methylimidazo $(5,1-d)-1,2,3,5$-tetrazin-4(3H)-one) and nitrosoureas (BCNU - carmustine, ACNU - nimustine, CCNU lomustine; referred to as CNUs). In contrast to CNUs, TMZ undergoes rapid non-enzymatic conversion at physiologic $\mathrm{pH}$ to its reactive compound 5-3-(methyl)-1(triazen-1-yl) imidazole-4-carboxamide (MTIC). MTIC is thought to cause DNA damage mainly by methylating the $\mathrm{O}^{6}$-position of guanine (primary lesion) which then mismatches with thymine in double-stranded DNA $\left(\mathrm{O}^{6} \mathrm{G}-\mathrm{T}\right)$ in the first cell cycle after treatment. This mismatch induces futile cycles of mismatch repair triggered by recurrent GT-mismatches resulting in either double strand breaks or a critical recombinogenic secondary lesion. This secondary lesion is assumed to be an apurinic/athymidinic site formed during faulty mismatch repair that blocks replication resulting in either DNA double strand breaks (tertiary lesion), sister chromatid exchange, or other aberrations [28-32]. Thus, not the primary lesions caused by TMZ, but the tertiary lesions formed during faulty mismatch repair, induce cell death of the affected tumor cells. Other mechanisms of action have also been described: TMZ can induce prolonged, p53 and p21 WAF1/Cip1 - mediated $\mathrm{G}_{2}-\mathrm{M}$ arrest beginning 2 days after treatment with a small number of cells undergoing apoptosis but most undergoing senescence over a 10-day period. In contrast, TMZ induces temporary G2-M arrest accompanied by only minor changes in p53 or p $21^{\text {WAF } 1 / C i p 1}$ expression in p53 deficient cells [33].

The most frequent sites of DNA base alkylation by CNUs are the $\mathrm{N}^{7}$-position of guanine and the $\mathrm{N}^{3}$-position of adenine [34,35]. In addition, CNUs mediate their cytotoxic effect by chloroethylation at the $\mathrm{O}^{6}$-position of guanine which produces an $\mathrm{N}^{1}$-deoxyguanosinyl- $\mathrm{N}^{3}$ deoxycytidyl crosslink that is poorly repaired and causes DNA strand break during mitosis. The type of cell death caused by CNU-induced DNA damage is dependent on the p53 status of the tumour cells. In p53 wildtype cells CNUs induce apoptotic cell death while they 
trigger necrotic cell death in p53 deficient cells [36]. Thus, CNUs are also active if a functional DNA repair system is lacking, whereas TMZ requires a well-established DNA repair system to be effective. The mechanisms of action of TMZ and CNUs suggest that differences in the DNA repair system of CSC and tumor cells without stem cell properties are important to understand any differential sensitivities of CSC to alkylating agents, and how these may arise.

In addition, it may help to understand a putative differential susceptibility of CSC to CNUs and TMZ. To present, three studies have investigated the DNA repair systems in GBM CSC. McCord et al. [37] compared the radioresistance of CSC lines and classical serum cultured cell lines. CSC lines showed a substantially impaired DNA repair resulting in a reduced radioresistance of CSC lines. Within a subset of CSC lines, the $\mathrm{CD}_{133^{+}}$cells were more resistant to irradiation with 2.5 Gy as compared to $\mathrm{CD}^{-} 133^{-}$non-stem cells. These data indicate that the mechanisms mediating CSC radioresponse differ from those in the traditional model. The report by McCord et al. complements an earlier report by Bao et al. [22] showing CSC resist radiotherapy due to a more efficient DNA system than non-stem cells. After irradiation, CSC activate the DNA damage checkpoint more effectively than tumor cells without stem cell properties due to the activation of Chk1 and Chk2 checkpoint kinases [22]. However, the differential activation of the DNA repair system in CSC has been questioned by a recent study [38] and it remains to be clarified if the more efficient DNA repair system postulated by Bao et al. [22] constitutes a common property of CSC. Given that TMZ requires an efficient DNA repair (namely the mismatch repair system) to exert its cytotoxic actions, a detailed knowledge of the DNA repair system in CSC as compared to non-CSC will be crucial to help our understanding how TMZ affects the survival of CSC. The functional role of the DNA repair system in CSC and non-CSC may be further complicated by recent data suggesting different molecular subtypes within GBM [39]. Because the subgroups also differ with respect to p53 mutations, the intertumoral heterogeneity will further increase the complexity of TMZ resistance and susceptibly.

\section{CSC and alkylating agents - results from serum-cultured GBM cell lines}

Although results derived from serum-cultured glioma cell lines may be biased by multiple new mutations induced during long-term culture in serum-containing medium $[40,41]$, several authors have described stem cell-like cells within these cell lines [42,43]. Therefore, experimental data collected in the "pre-CSC era" may provide some clues to the effects of TMZ on CSC and the mechanisms of action. The induction of tumor cell death has been considered as the most important contribution of a therapeutic drug to the overall treatment efficacy. Roos et al. [44] showed that TMZ-induced receptor-mediated or mitochondrial apoptosis in glioma cells was depending on their p53 status. Irrespective of the p53 status, after long-term incubation with TMZ (for up to $144 \mathrm{~h}$ ), dose-dependent apoptosis occurred at late time points starting after 72-96 h. However, even after continuous exposure to TMZ doses of up to 500 $\mu \mathrm{M}$, at least $30 \%$ viable cells remained. Similar results were described by Hermisson et al. [45] investigating the effects of TMZ on a panel of different glioma cell lines. Even high concentrations of TMZ (up to 1290 $\mu \mathrm{M})$ resulted in the survival of up to $40 \%$ of the cells, indicating cytostatic rather than cytotoxic actions of TMZ in these assays. Interestingly, colony-formation seemed to be much more sensitive to treatment with TMZ even after short-term incubation for only $24 \mathrm{~h}$. The $\mathrm{EC}_{50}$ values for the prevention of clonogenic growth ranged between $7 \mu \mathrm{M}$ and $511 \mu \mathrm{M}$ and correlated with the MGMT status of the cell lines. Hirose et al. [33] treated p53 wild-type cells with $100 \mu \mathrm{M}$ TMZ for $3 \mathrm{~h}$. The population of apoptotic cells did not exceed $10 \%$ but clonogenicity was dose-dependently decreased or completely inhibited. The results of these three publications are representative of multiple reports from glioma and other brain tumor cell lines, reporting almost uniformly a much stronger effect of TMZ on clonogenic growth than on the overall survival of glioma cell lines in vitro [33,46-48].

CNUs are more toxic to p53 mutant cells as compared to TMZ. As reported by Roos et al. [36], ACNU-induced cross-links or double strand breaks are repaired in p53 wild-type cells but accumulate in p53 mutant cells. In addition, the repair genes xpc and ddb2 were not upregulated in p53 mutant cells in response to ACNU indicating a DNA repair defect in the cells causing hypersensitivity to CNUs. On a functional level, colony-formation was much more sensitive to treatment with CNUs than cell viability which did not fall below $30 \%$. In addition, cell death was a late occurring event [36]. Similar findings were reported by Bobola et al. [47], Ashley et al. [49], and Iwado et al. [48]. Together, the majority of reports suggest that CNUs preferentially eliminate clonogenic cells but hardly affect the overall viability. Still, this effect was less pronounced than with TMZ.

In summary, there is a consensus in the literature that the clonogenic growth monitored by colony-forming assays is much more sensitive to treatment with either TMZ or CNUs in vitro as compared to the overall cell death in vitro. These findings do not suggest an increased resistance of clonogenic cells (including CSC) towards TMZ or other alkylating agents. 
However, none of the papers investigated CSC in detail or used assays specific for CSC. As non-stem cells may also show clonogenic growth without being able to proliferate infinitely, the results have to be interpreted with caution [50]. In addition, clonogenic growth is the sum of all events occurring after treatment (including a. o. cell cycle arrest, cell death) and therefore does not allow definite conclusions on the cause of clonogenic cell inactivation.

\section{CSC and alkylating agents - results from GBM CSC lines}

Several recent studies have focused on the effects of chemotherapy on CSC. The CSC hypothesis led to the development of a new cell culture model for GBM. GBM cell lines derived from freshly resected tumor specimens and cultured in serum-free medium supplemented with EGF and bFGF - conditions optimized for the growth of neural stem cells - mirror the phenotype and genotype of primary tumors more closely than serumcultured cell lines do $[40,41]$. Thus, experiments with this new cell culture model may yield more valid results on the efficacy of therapeutic agents. The relevance of conventional cell lines (cultured under mainly serumbased media conditions) as means to investigate CSC is disputed. Although the results may be biased by multiple new mutations induced during long-term culture in serum-containing media, these studies are also discussed here. Table 1 gives an overview of studies discussed and indicates the possible technical limitations and key findings of each study.

Eramo et al. were the first to investigate the chemoresistance of GBM CSC. A marked resistance was observed of GBM CSC lines to different chemotherapeutic agents, amongst them TMZ. GBM CSC lines were treated with $250 \mu \mathrm{M}$ TMZ for $48 \mathrm{~h}$ and minor cell death was determined as a measure of treatment efficacy [51]. Using the same culture model, Clement et al. observed a dose-dependent decrease of proliferation when $\mathrm{CD} 133^{+} \mathrm{CSC}$ lines were treated with up to 100 $\mu \mathrm{M}$ TMZ, whereas only a minor increase of cell death was observed at similar concentrations [52]. The authors compared the effects of TMZ with the inhibition of the hedgehoc-GLI1 (shh) signaling pathway and found synergistic activity of shh signaling and TMZ. Notably, administration of each of these substances inhibited cell proliferation, although to a different degree. The effects of TMZ treatment on the tumorigenicity of GBM CSC were not investigated. Beier et al. described that TMZ may selectively deplete clonogenic and tumorigenic cells in a dose-dependent manner whereas it hardly affected overall viability. When $\mathrm{CD}_{13}{ }^{+} \mathrm{CSC}$ lines derived from primary astrocytic GBM were treated with up to 500 $\mu \mathrm{M}$ TMZ over different periods of time ( $2 \mathrm{~d}$ and $42 \mathrm{~d}$ ), there was a dose-dependent reduction of $\mathrm{CD} 133^{+}$cells (by $80 \%$ ), cell proliferation (by up to $100 \%$ ), as well as clonogenicity and tumorigenicity (by up to 100\%), whereas cell death did not exceed $6 \%$. Cells with stem cell-like properties were selectively depleted irrespective of the CD133 or MGMT status. However, MGMT expressing CSC lines required up to 100 fold higher TMZ concentrations. In summary, the authors interpreted their results as selective depletion of CSC from CSC lines by TMZ [53]. Additional confirmatory experiments (e.g. treatment of tumor bearing mice or characterization of tumor material direct after resection) have not been performed. In addition, the authors only investigated three different TMZ concentrations.

In contrast to these reports, Liu et al. used CSC lines that have been established using serum and switched to serum-free culture conditions before the experiments. The authors found that sorted $\mathrm{CD} 133^{+} \mathrm{CSC}$ showed significant resistance to chemotherapeutic agents (including, amongst others, TMZ). The viability of CD $133^{+}$ cells was significantly less decreased than the viability of CD133- tumor cells when treated with up to $2000 \mu \mathrm{M}$ TMZ for $48 \mathrm{~h}$. Notably, even this concentration did not induce cell death in more than $50 \%$ of the cells [54]. Ghods et al. investigated chemoresistant and aggressive CSC-like cells within the serum cultured 9L gliosarcoma rat cell line. Viability of 9L cells grown in serum-containing medium as a monolayer and 9L cells grown after serum-deprivation as spheres were compared. The 9L cells grown as spheres were more chemoresistant than cells grown as monolayers. Thus, the authors concluded that CSC were more chemoresistant [55]. Bleau et al. investigated the side population phenotype cells within murine glioma CSC lines derived from PDGF-induced gliomas after TMZ treatment. In line with a report by Chua et al. [56], the number of side population phenotype cells increased, especially in cells lacking PTEN expression, when CSC lines were treated with up to 100 $\mu \mathrm{M}$ TMZ for up to 2 weeks [57]. This translated into an increased tumorigenicity of the long-term TMZ treated cell lines. Unfortunately, neither the MGMT status of the CSC nor the effects of TMZ on stem cell properties were determined. However, the different tumorigenicity of treated and untreated CSC indicated that TMZ increased the number of CSC. Blough et al. investigated the sensitivity of 20 GBM-derived CSC lines cultured under standard conditions [58]. They found that 9 out of 20 CSC lines were susceptible to TMZ, while 11 were resistant. The expression of MGMT, but not methylation of the MGMT promoter, indicated TMZ response in vitro. A correlation of CD133 expression and resistance towards TMZ was not reported [59]. TMZ substantially eliminated the proportion of $\mathrm{CD}_{133^{+}}$stem cell-like cells in a study by Lamoral-Theys et al. using oligodendroglioma HS683 cells. HS683 cells were 
Table 1 Summary of studies investigating CSC and TMZ

\begin{tabular}{|c|c|c|c|}
\hline Author & $\begin{array}{l}\text { serum free medium } \\
\text { used? }\end{array}$ & Key findings (on TMZ and CSC) & Problems \\
\hline Eramo et al. (2006) & Yes & $\begin{array}{l}\text { High resistance of neurosphere cultures to different } \\
\text { drugs }\end{array}$ & $\begin{array}{l}\text { No detailed investigation of stem cell } \\
\text { properties. }\end{array}$ \\
\hline Liu et al. (2006) & $\begin{array}{l}\text { Initial culture with } \\
\text { serum }\end{array}$ & $\begin{array}{l}\text { Differential susceptibility of } \mathrm{CD} 133^{+} \text {as compared to } \\
\text { CD133- cells }\end{array}$ & $\begin{array}{l}\text { No confirmation in vivo, non- } \\
\text { physiological TMZ concentrations }\end{array}$ \\
\hline Clement et al. (2007) & Yes & Reduced clonogenicity by TMZ. & $\begin{array}{l}\text { Study did not investigate TMZ effects in } \\
\text { detail. }\end{array}$ \\
\hline Ghods et al. (2007) & No & $\begin{array}{l}\text { Gliosarcoma cells grown as neurospheres were more } \\
\text { resistant to TMZ than the same cells grown as } \\
\text { monolayer. }\end{array}$ & $\begin{array}{l}\text { Study did not control for different } \\
\text { growth conditions (spheres vs. } \\
\text { monolayer). }\end{array}$ \\
\hline Chua et al. (2008) & No & Increase of SP cell population after TMZ treatment. & $\begin{array}{l}\text { No in vivo study on tumorigenicity, } \\
\text { serum cultured cell lines (U87). }\end{array}$ \\
\hline Beier et al. (2008) & Yes & $\begin{array}{l}\text { Depletion of clonogenic and tumorigenic cells by } \\
\text { TMZ. }\end{array}$ & Only a few concentrations investigated. \\
\hline Bleau et al. (2009) & $\begin{array}{l}\text { No (serum-free } \\
\text { medium only for } \\
\text { neurosphere } \\
\text { experiments) }\end{array}$ & $\begin{array}{l}\text { Increased tumorigenicity of glioma cell derived from } \\
\text { murine glioma model after long term TMZ treatment } \\
\text { (14d). First study that proved that TMZ may increase } \\
\text { the tumorigenicity of gliomas. }\end{array}$ & $\begin{array}{l}\text { Murine cells, no information on MGMT } \\
\text { methylation status. }\end{array}$ \\
\hline Blough et al. (2010) & Yes & $\begin{array}{l}\text { Susceptiblity of CSC lines dependent on MGMT } \\
\text { expression and promoter status. }\end{array}$ & $\begin{array}{l}\text { No detailed assessement of stem cell } \\
\text { properties. }\end{array}$ \\
\hline Larmoral-Theys et al. (2010) & No & $\begin{array}{l}\text { Decreased tumorigenicity of an oligodendroglial cell } \\
\text { line after long-term TMZ treatment. }\end{array}$ & $\begin{array}{l}\text { Serum cultured cell lines; no detailed } \\
\text { assessment of stem cell properties. }\end{array}$ \\
\hline Glas et al. (2010) & Yes & $\begin{array}{l}\text { Differential susceptibility of peripheral and central } \\
\text { CSC lines to TMZ. No constant difference between } \\
\text { central and peripheral samples. }\end{array}$ & $\begin{array}{l}\text { No systematic assessment of stem cell } \\
\text { properties and MGMT status. Conflicting } \\
\text { data to Pistolatto et al. }\end{array}$ \\
\hline Pistolatto et al. (2010) & Yes & $\begin{array}{l}\text { Higher resistance of central, hypoxic CD133 CSC as } \\
\text { compared to cells derived from the periphery due to } \\
\text { increased MGMT expression. }\end{array}$ & $\begin{array}{l}\text { No validation in a larger set of samples. } \\
\text { Conflicting data to Glas et al. }\end{array}$ \\
\hline Mihaliak et al. (2010) & Yes & $\begin{array}{l}\text { Initial reduction of neurosphere-like growth after } \\
\text { TMZ challenge; recovery in } 4 / 5 \text { CSC lines. }\end{array}$ & $\begin{array}{l}\text { No assessment of the MGMT status; only } \\
\text { a few concentrations investigated. }\end{array}$ \\
\hline Gilbert et al. (2010) & Yes & $\begin{array}{l}\text { Initial reduction of neurosphere-like growth after } \\
\text { TMZ challenge; inhibition of neurosphere recovery } \\
\text { using by NOTCH inhibition. }\end{array}$ & See comment on Milhaliak et al. \\
\hline Villalva et al. (2011) & Yes & Decreased clonogenicity after treatment with TMZ. & $\begin{array}{l}\text { Study did not investigate TMZ effects in } \\
\text { detail. }\end{array}$ \\
\hline Hsieh et al. (2010) & Yes & $\begin{array}{l}\text { Activation of IGF or shh increases the resistance of } \\
\text { CSC to TMZ. Differentiated CSC (with 10\% serum) } \\
\text { were more susceptible to acute TMZ toxicity than } \\
\text { CSC lines. }\end{array}$ & $\begin{array}{l}\text { No controls for different growth } \\
\text { conditions (spheres vs. monolayer and } \\
\text { serum vs. stem cell medium) mentioned. }\end{array}$ \\
\hline
\end{tabular}

cultured using serum, but not using medium conditions optimized for CSC. The authors found that long-term treatment of HS683 cells with increasing concentrations of TMZ (from $0.1 \mu \mathrm{M}$ to $1000 \mu \mathrm{M}$ ) resulted in a substantially decreased tumorigenicity of long-term treated cells, despite a wash-out phase of 8 weeks after TMZ treatment. Notably, the long-term treatment reduced the tumorigenicity and CD133 expression much more effectively than short-term treatment, indicating that the dosing schema influences the depletion of CSC in vitro. The MGMT expression remained unchanged in both groups [60]. Villalva et al. investigated effects of STAT3 inhibition and TMZ using CSC lines. They found that both, inhibition of STAT3 and TMZ, substantially inhibited the clonogenic growth of CSC lines and both substances showed a strong synergy [61]. Similar results were reported by Hsieh et al. who investigated the effects of IGF-1 and shh signaling in CSC lines [62].

Based on the high toxicity of TMZ to neurosphereforming cells within CSC lines, Mihaliak et al. [63] developed a neurosphere recovery assay that was used to investigate the resistance of GBM in the patients. Interestingly and in line with data by Blough et al. [59] and Beier al. [53], they found that the clinically relevant concentrations were able to inhibit the growth of neurospheres in a subgroup of CSC lines and reduced their tumorigenicity. In contrast to the data published by Beier et al., TMZ completely depleted clonogenic cells in only 1 out of 5 CSC lines investigated. NOTCH inhibition successfully inhibited the recovery of 
neurospheres after successful depletion of clonogenic cells in vitro [64].

Two recent studies investigated the susceptibility of CSC derived from the core and the periphery of GBM in vivo: Pistollato et al. [65] focused on the effects of the intratumoral hypoxic gradient on the distribution, phenotype and TMZ resistance of CSC. They established and compared CSC lines from the core, the intermediate area, and the periphery of GBM. CSC lines from the periphery showed a higher susceptibility to TMZ induced cell death as compared to CSC from the core. Conversely, cells in the core frequently overexpressed CD133 and MGMT. In summary, the authors postulated that the hypoxic gradient drives the distribution of stem cells. A complementary report by Glas et al. [66] confirmed the differential responses of CSC lines derived from the core and the periphery in a subgroup of GBM, however in most of the samples, there was no uniform difference in the response of the corresponding CSC lines towards TMZ, CNUs, or radiation (alone or in combination).

To present, only one paper has thoroughly investigated the effects of CNUs on CSC lines [67]. Based on an increased expression of the stem cell marker CD133 and a neurosphere-like growth pattern of resistant cells, the authors concluded that $\mathrm{BCNU}$ increased the proportion of CSC in the cell lines investigated.

Due to differences in experimental approaches, these studies are difficult to compare. Given that serum-cultured cell lines rapidly acquire multiple mutations and substantially differ from the original tumor, they may provide conflicting results as compared to studies using medium conditions favoring the growth of CSC. However, most recent studies used CSC lines continuously cultured under serum-free conditions. In summary, Eramo et al., Bleau et al., and Pistollato et al. reported an increased resistance of CSC while Beier et al., Bleau et al., Mihaliak et al., Gilbert et al., and Clement et al. described experimental data relating to CSC and TMZ which is consistent with an increased susceptibility of CSC towards TMZ. The data presented by Glas et al., do not allow unambiguous conclusions on the susceptibility of CSC towards chemotherapy (overview in Table 1).

The data presented in the above-mentioned papers allows several conclusions and points towards open questions: (I) All papers uniformly reported that MGMT protein expression is associated with a high resistance of CSC to TMZ. However the role of other factors known to modulate chemoresistance has not been investigated in detail. (II) Whenever investigated in detail, neurosphere-forming cells without MGMT expression were susceptible to TMZ. (III) Different TMZ schedules and concentrations may result in conflicting experimental results. (IV) Environmental factors, like hypoxia in the core of GBM, may contribute to the resistance of CSC towards TMZ. (V) Several signaling pathways, e.g. Shh, IGF-1/PI-3 kinase, NOTCH, or STAT3 interfere with TMZ resistance. (VI) There is no consensus on adequate methodologies to investigate CSC in vitro.

\section{Intrinsic chemoresistance}

A set of papers (listed in Table 1) on CSC and TMZ focused on the factors modulating chemoresistance of CSC to alkylating agents. In vitro, approximately half of all GBM cell lines resisted to TMZ concentrations of $50 \mu \mathrm{M}$ $[45,53,59]$. They obviously activated mechanisms of intrinsic chemoresistance (Figure 1). To date, MGMT is the best characterized and the most important modulator of chemoresistance in GBM [68-71]. There is consensus in the literature that MGMT expression substantially increases the resistance of CSC $[53,54,59,65]$. However, there is conflicting data regarding overexpression of MGMT in the stem cell compartment [53,54]. The expression of MGMT in GBM CSC results in a 10-fold increase of TMZ-resistance [45,53]. The resistance of MGMT expressing CSC [59] fits well to the clinical observations that patients without methylation of the MGMT promoter rarely survive longer than 2 years [69]. In these tumors, all cells may have an obvious intrinsic resistance to TMZ. However, relapsing GBM maintained by CSC without intrinsic resistance to TMZ are difficult to understand, assuming an intrinsic susceptibility of CSC.

The role of multi-drug resistance proteins is controversial. Although expressed in GBM cells, it remains unknown whether TMZ is actually transported by these proteins. Although TMZ incubation increased the proportion of ABCG1 expressing cells (i.e. side population cells) [56], TMZ was not a substrate for the ABCG1 transporter in murine glioma cells [72]. Schaich et al. reported that MDR1 (ABCB1) mediated TMZ resistance and was an independent predictor for TMZ responsiveness [73].

TMZ requires an intact mismatch repair system to cause toxic double stranded breaks. Thus, mutations in the major crucial component of the mismatch repair system mutS homolog 6 (MSH6) mediated TMZ resistance especially in recurrent GBM after TMZ-based radiochemotherapy $[74,75]$. A well-characterized mechanism of resistance inhibits cell death induced by double stranded breaks. Signalling cascades involved include mutations of p53 and Poly(ADP-ribose)polymerase (PARP) signalling and mutations modulating the apoptotic cascade that executes double stranded breakinduced apoptosis [44,76]. Additional but less well-characterized proteins contributing to chemoresistance include protein glutathione-S-transferase. To date, none of these mechanisms of chemoresistance in CSC lines have been investigated in detail. 


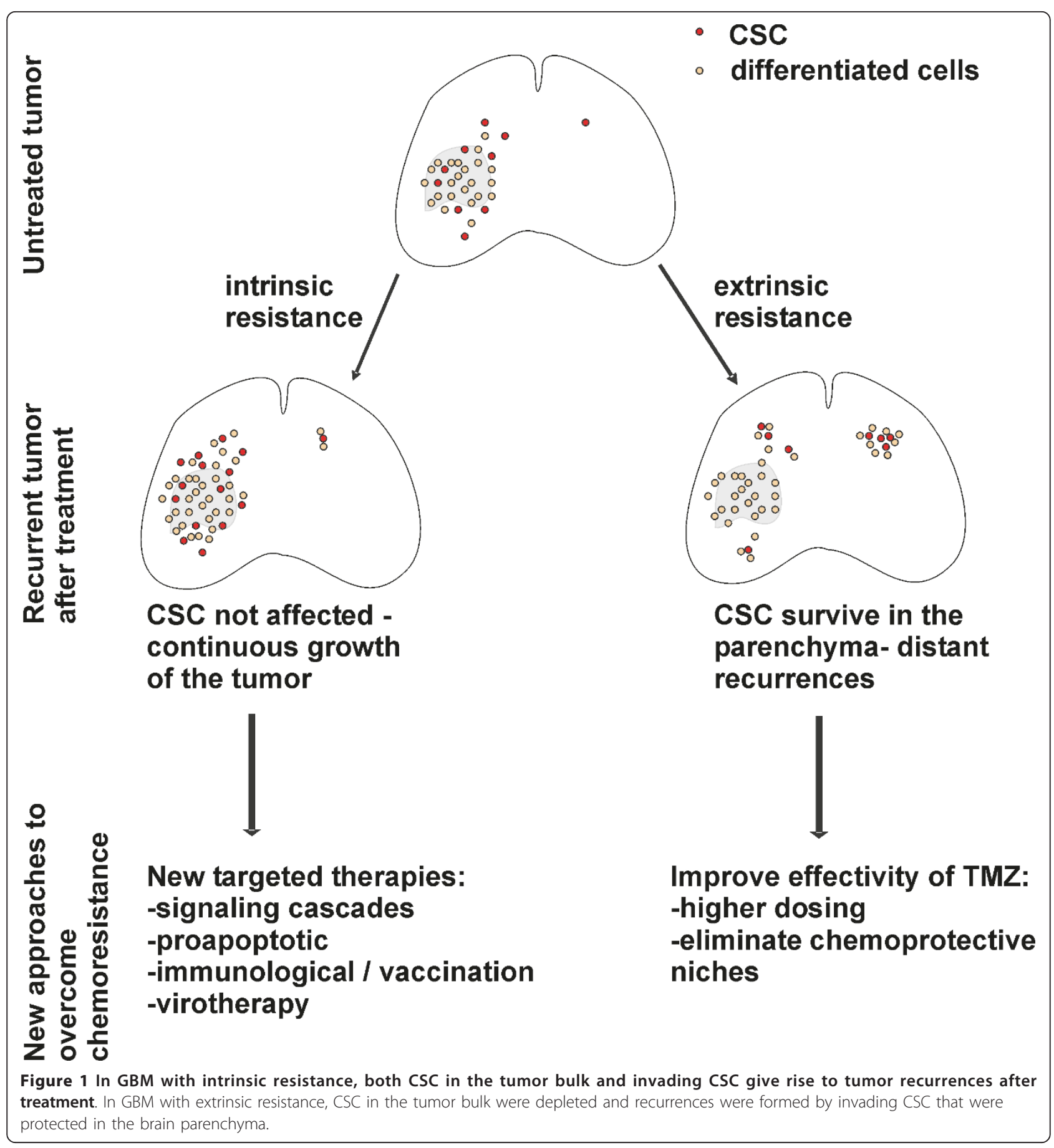

In addition, the fate of CSC after TMZ treatment in vitro and in vivo remains unknown, although a loss of stem cell properties in GBM CSC lines and a pronounced sensitivity of colony-formation to treatment with TMZ has been observed in serum cultured cell lines [33,45-48]. In susceptible GBM, TMZ can induce only long lasting cell cycle arrest (G2/M arrest) [33,77], senescence $[78,79]$, or autophagy $[80,81]$. However, despite the mismatch of minor cell death and massively reduced colony-formation, apoptotic cell death $[33,44,48,82]$ always occurs.

Extrinsic mechanisms of chemoresistance

Under experimental conditions, TMZ may completely eliminate CSC, suggesting that a selective depletion in vitro is feasible [53]. In contrast, the survival of patients 
treated with TMZ did not stabilize [7] suggesting that residual CSC survived in vivo (Figure 1).

The blood-brain-barrier constitutes a specific hurdle for drugs in the brain that reduces the activity of chemotherapy due to decreased concentrations in the brain parenchyma. In approximately $50 \%$ of all glioma cells lines, clonogenic cells and/or GBM CSC were highly susceptible to TMZ concentrations of $50 \mu \mathrm{M}$ in vitro. Still, TMZ concentrations of $5 \mu \mathrm{M}$ did not deplete clonogenic cells in vitro irrespective of cell culture model or MGMT status $[45,53,59]$. The actual concentrations achieved in the plasma and the brain parenchyma of the patients are therefore important to understand if and where within a GBM TMZ concentrations suffice to eliminate tumor cells, irrespective of stem cell properties. The maximum TMZ concentrations in the plasma of patients are well established and range between 27 $\mu \mathrm{M}$ and $50 \mu \mathrm{M}$ [83]. In contrast, the maximum TMZ concentration in the brain is still unknown. PET studies suggested a concentration of $10-18 \mu \mathrm{M}$ in the normal parenchyma, however, this methodology does not differentiate between intravasal and interstitial TMZ [84]. In CSF, maximal TMZ concentrations ranged from 0.5-10 $\mu \mathrm{M}$ with most patients achieving concentrations around $5 \mu \mathrm{M}$ (i.e. $1 \mu \mathrm{g} / \mathrm{ml}$ ) [85]. These values were confirmed by a study reporting on interstitial TMZ concentrations of $3 \mu \mathrm{M}$ [86]. Although detailed studies are lacking, it appears plausible that tumour cells within the contrastenhancing lesions (i.e. regions of impaired blood-brain barrier) are exposed to concentrations approximating plasma concentrations. In contrast, invading tumours cells are likely to be exposed to concentrations measured in the healthy brain parenchyma (approximately 3-5 $\mu \mathrm{M})$. Unfortunately, similar studies for CNUs are lacking. Knowing the susceptibility of CSC in vitro, these studies strongly suggest that the incomplete penetration of the blood-brain barrier by TMZ may constitute a major factor for chemoresistance of invading CSC. In line with this idea, a recent report analyzing the recurrence patterns of GBM could show that MGMT non-methylated GBM tend to relapse at the site of primary occurrence [87] whereas MGMT-methylated GBM showed a significantly higher proportion of distant metastases. However, this report remains controversial [88] and the concept described does not explain why susceptible GBM also develop recurrences develop from contrast enhancing lesions under ongoing TMZ therapy.

Extrinsic factors of the microenvironment contribute to the chemoresistance of haematological and solid tumors (reviewed in [89]). In these tumors, three different mechanisms of environmentally-mediated chemoresistance have been described: direct cell-cell interactions, local secretion of cytokines like IL- 6 or SFD-1, or micro-environmental factors such as hypoxia
[89,90]. Although these mechanisms may substantially contribute to chemoresistance of GBM there is only indirect evidence to suggest that these mechanisms may be relevant for GBM CSC. Villalva et al. showed that the activation of STAT3 increases the resistance of CSC to TMZ [61]. Given the expression of IL-6 protein family members like LIF in GBM [91], it is likely that they contribute to chemoresistance of GBM CSC.

\section{Loss of cellular hierarchy as new mechanism for chemoresistance to $\mathrm{TMZ}$}

The CSC hypothesis predicted that the selective elimination of CSC would halt the perpetual growth and tumorigenicity of tumor cells. However, this hierarchy was recently called into question $[14,50]$. It was suggested that the "stemness" of tumor cells may be induced by niche factors such as hypoxia [65,92-94]. Conversely, these data imply that tumor cells may acquire CSC properties. Several lines of evidence support this concept: Wang et al. were the first to show that CD133-negative tumors may acquire CD133 in a xenotransplantation model [13]. More recently, Chen et al. reported that different types of CSC within one cell line. Within a given cell line, CSC may give rise to other subtypes suggesting a less stringent cellular hierarchy [14]. In melanoma, Morrison et al. showed that these tumors may entirely lack a cellular hierarchy [95]. The generation of new CSC from differentiated cells may therefore represent a new mechanism for therapeutic resistance after selective elimination of CSC [8]. However, additional experimental data is required to confirm this concept.

\section{Summary and Outlook}

There is no consensus in the literature on the effects of chemotherapeutic drugs on GBM CSC in vivo or in vitro. Still, the available experimental data clearly indicate that resistance of GBM and derived CSC against TMZ is much more complex than expected. The initial predictions of the CSC hypothesis remain true under specific experimental conditions but multiple additional aspects have to be considered to understand why GBM almost invariably relapse. This review summarizes several known aspects of chemoresistance; additional contributors are likely to be discovered. A more comprehensive view will help to better understand the multifaceted factors that contribute to the survival or reoccurrence of CSC causing fatal relapses in the patient.

\section{Acknowledgements}

This work was supported by a career award to young female scientists of the RWTH Aachen, Medical School to DB. Parts of the project were funded by BayGene and the NGFNplus Brain Tumor Network to CPB (Subproject 7B 
No. 01GS1105) and the in-house research support of the RWTH Aachen, Medical School (START-Program) to DB. We would like to thank Rosin Ana for carefully proof-reading the manuscript.

\section{Authors' contributions}

$\mathrm{DB}, \mathrm{JBS}$, and CPB wrote and finally approved the manuscript.

\section{Competing interests}

CPB has received an unrestricted travel grant from Schering Plough in 2008. All other authors declare that they have no competing interests.

Received: 13 March 2011 Accepted: 11 October 2011

Published: 11 October 2011

\section{References}

1. Weller M, Muller B, Koch R, Bamberg M, Krauseneck P: Neuro-Oncology Working Group 01 trial of nimustine plus teniposide versus nimustine plus cytarabine chemotherapy in addition to involved-field radiotherapy in the first-line treatment of malignant glioma. J Clin Oncol 2003, 21:3276-3284.

2. Walker MD, Alexander E Jr, Hunt WE, MacCarty CS, Mahaley MS Jr, Mealey J Jr, Norrell HA, Owens G, Ransohoff J, Wilson CB, Gehan EA, Strike TA: Evaluation of BCNU and/or radiotherapy in the treatment of anaplastic gliomas. A cooperative clinical trial. J Neurosurg 1978, 49:333-343.

3. Stupp R, Mason WP, van den Bent MJ, Weller M, Fisher B, Taphoorn MJ, Belanger K, Brandes AA, Marosi C, Bogdahn U, Curschmann J, Janzer RC Ludwin SK, Gorlia T, Allgeier A, Lacombe D, Cairncross JG, Eisenhauer E, Mirimanoff RO: Radiotherapy plus concomitant and adjuvant temozolomide for glioblastoma. N Engl J Med 2005, 352:987-996.

4. Yung WK, Albright RE, Olson J, Fredericks R, Fink K, Prados MD, Brada M, Spence A, Hohl RJ, Shapiro W, Glantz M, Greenberg H, Selker RG, Vick NA, Rampling R, Friedman H, Phillips P, Bruner J, Yue N, Osoba D, Zaknoen S, Levin VA: A phase II study of temozolomide vs. procarbazine in patients with glioblastoma multiforme at first relapse. Br J Cancer 2000, 83:588-593.

5. Beier CP, Schmid C, Gorlia T, Kleinletzenberger C, Beier D, Grauer O, Steinbrecher A, Hirschmann B, Brawanski A, Dietmaier C, Jauch-Worley T, Pietsch T, Proescholdt M, Rummele P, Muigg A, Stockhammer G, Hegi M, Bogdahn U, Hau P: RNOP-09: pegylated liposomal doxorubicine and prolonged temozolomide in addition to radiotherapy in newly diagnosed glioblastoma - a phase II study. BMC Cancer 2009, 9:308.

6. Hau P, Koch D, Hundsberger T, Marg E, Bauer B, Rudolph R, Rauch M, Brenner A, Rieckmann P, Schuth J, Jauch T, Koch H, Bogdahn U: Safety and feasibility of long-term temozolomide treatment in patients with highgrade glioma. Neurology 2007, 68:688-690.

7. Stupp R, Hegi ME, Mason WP, van den Bent MJ, Taphoorn MJ, Janzer RC, Ludwin SK, Allgeier A, Fisher B, Belanger K, Hau P, Brandes AA, Gijtenbeek J, Marosi C, Vecht CJ, Mokhtari K, Wesseling P, Villa S, Eisenhauer E, Gorlia T, Weller M, Lacombe D, Cairncross JG, Mirimanoff RO: Effects of radiotherapy with concomitant and adjuvant temozolomide versus radiotherapy alone on survival in glioblastoma in a randomised phase III study: 5-year analysis of the EORTC-NCIC trial. Lancet Oncol 2009, 10:459-466.

8. Reya T, Morrison SJ, Clarke MF, Weissman IL: Stem cells, cancer, and cancer stem cells. Nature 2001, 414:105-111.

9. Singh SK, Hawkins C, Clarke ID, Squire JA, Bayani J, Hide T, Henkelman RM, Cusimano MD, Dirks PB: Identification of human brain tumour initiating cells. Nature 2004, 432:396-401.

10. Galli R, Binda E, Orfanelli U, Cipelletti B, Gritti A, De Vitis S, Fiocco R, Foroni $C$, Dimeco F, Vescovi A: Isolation and characterization of tumorigenic, stem-like neural precursors from human glioblastoma. Cancer Res 2004, 64:7011-7021.

11. Kemper K, Sprick MR, de Bree M, Scopelliti A, Vermeulen L, Hoek M, Zeilstra J, Pals ST, Mehmet H, Stassi G, Medema JP: The AC133 Epitope, but not the CD133 Protein, Is Lost upon Cancer Stem Cell Differentiation. Cancer Research 2010, 70:719-729.

12. Wan F, Zhang S, Xie R, Gao B, Campos B, Herold-Mende C, Lei T: The Utility and Limitations of Neurosphere assay, CD133 Immunophenotyping and Side Population Assay in Glioma Stem Cells Research. Brain Pathology 2010, 9999.
13. Wang J, Sakariassen PO, Tsinkalovsky O, Immervoll H, Boe SO, Svendsen A, Prestegarden L, Rosland G, Thorsen F, Stuhr L, Molven A, Bjerkvig R, Enger PO: CD133 negative glioma cells form tumors in nude rats and give rise to CD133 positive cells. Int J Cancer 2008, 122:761-768.

14. Chen R, Nishimura MC, Bumbaca SM, Kharbanda S, Forrest WF, Kasman IM, Greve JM, Soriano RH, Gilmour LL, Rivers CS, Modrusan Z, Nacu S, Guerrero S, Edgar KA, Wallin JJ, Lamszus K, Westphal M, Heim S, James CD, VandenBerg SR, Costello JF, Moorefield S, Cowdrey CJ, Prados M, Phillips HS: A hierarchy of self-renewing tumor-initiating cell types in glioblastoma. Cancer Cell 2010, 17:362-375.

15. Joo KM, Kim SY, Jin X, Song SY, Kong DS, Lee Jl, Jeon JW, Kim MH, Kang BG, Jung Y, Jin J, Hong SC, Park WY, Lee DS, Kim H, Nam DH: Clinical and biological implications of CD133-positive and CD133-negative cells in glioblastomas. Lab Invest 2008, 88:808-815.

16. Gunther HS, Schmidt NO, Phillips HS, Kemming D, Kharbanda S, Soriano R, Modrusan Z, Meissner H, Westphal M, Lamszus K: Glioblastoma-derived stem cell-enriched cultures form distinct subgroups according to molecular and phenotypic criteria. Oncogene 2008, 27:2897-2909.

17. Beier D, Hau P, Proescholdt M, Lohmeier A, Wischhusen J, Oefner PJ, Aigner L, Brawanski A, Bogdahn U, Beier CP: CD133(+) and CD133(-) glioblastoma-derived cancer stem cells show differential growth characteristics and molecular profiles. Cancer Res 2007, 67:4010-4015.

18. Ogden AT, Waziri AE, Lochhead RA, Fusco D, Lopez K, Ellis JA, Kang J, Assanah M, McKhann GM, Sisti MB, McCormick PC, Canoll P, Bruce JN: Identification of A2B5+CD133- tumor-initiating cells in adult human gliomas. Neurosurgery 2008, 62:505-514, discussion 514-505.

19. Lathia JD, Gallagher J, Heddleston JM, Wang J, Eyler CE, Macswords J, Wu Q, Vasanji A, McLendon RE, Hjelmeland AB, Rich JN: Integrin alpha 6 regulates glioblastoma stem cells. Cell Stem Cell 2010, 6:421-432.

20. Read TA, Fogarty MP, Markant SL, McLendon RE, Wei Z, Ellison DW, Febbo PG, Wechsler-Reya RJ: Identification of CD15 as a marker for tumor-propagating cells in a mouse model of medulloblastoma. Cancer Cell 2009, 15:135-147.

21. Son MJ, Woolard K, Nam DH, Lee J, Fine HA: SSEA-1 is an enrichment marker for tumor-initiating cells in human glioblastoma. Cell Stem Cell 2009, 4:440-452.

22. Bao S, Wu Q, McLendon RE, Hao Y, Shi Q, Hjelmeland AB, Dewhirst MW, Bigner DD, Rich JN: Glioma stem cells promote radioresistance by preferential activation of the DNA damage response. Nature 2006 444:756-760

23. Hirschmann-Jax C, Foster AE, Wulf GG, Nuchtern JG, Jax TW, Gobel U, Goodell MA, Brenner MK: A distinct "side population" of cells with high drug efflux capacity in human tumor cells. Proc Natl Acad Sci USA 2004, 101:14228-14233.

24. Macdonald DR, Cascino TL, Schold SC Jr, Cairncross JG: Response criteria for phase II studies of supratentorial malignant glioma. J Clin Oncol 1990, 8:1277-1280

25. Clarke MF, Dick JE, Dirks PB, Eaves CJ, Jamieson CH, Jones DL, Visvader J, Weissman IL, Wahl GM: Cancer stem cells-perspectives on current status and future directions: AACR Workshop on cancer stem cells. Cancer Res 2006, 66:9339-9344.

26. Pollard SM, Yoshikawa K, Clarke ID, Danovi D, Stricker S, Russell R, Bayani Head R, Lee M, Bernstein M, Squire JA, Smith A, Dirks P: Glioma stem cell lines expanded in adherent culture have tumor-specific phenotypes and are suitable for chemical and genetic screens. Cell Stem Cell 2009, 4:568-580.

27. Reynolds BA, Vescovi AL: Brain cancer stem cells: Think twice before going flat. Cell Stem Cell 2009, 5:466-467, author reply 468-469.

28. Karran P, Offman J, Bignami M: Human mismatch repair, drug-induced DNA damage, and secondary cancer. Biochimie 2003, 85:1149-1160.

29. Ochs K, Kaina B: Apoptosis induced by DNA damage O6-methylguanine is $\mathrm{BCl}-2$ and caspase- $9 / 3$ regulated and Fas/caspase- 8 independent. Cancer Res 2000, 60:5815-5824.

30. Kaina B, Ziouta A, Ochs K, Coquerelle T: Chromosomal instability, reproductive cell death and apoptosis induced by 06-methylguanine in Mex-, Mex+ and methylation-tolerant mismatch repair compromised cells: facts and models. Mutat Res 1997, 381:227-241.

31. Karran $\mathrm{P}$, Bignami M: DNA damage tolerance, mismatch repair and genome instability. Bioessays 1994, 16:833-839.

32. Roos WP, Kaina B: DNA damage-induced cell death by apoptosis. Trends Mol Med 2006, 12:440-450. 
33. Hirose $Y$, Berger MS, Pieper RO: p53 effects both the duration of G2/M arrest and the fate of temozolomide-treated human glioblastoma cells. Cancer Res 2001, 61:1957-1963.

34. Johannessen TC, Bjerkvig R, Tysnes BB: DNA repair and cancer stem-like cells-potential partners in glioma drug resistance? Cancer Treat Rev 2008, 34:558-567.

35. Fischhaber PL, Gall AS, Duncan JA, Hopkins PB: Direct demonstration in synthetic oligonucleotides that N,N'-bis(2-chloroethyl)-nitrosourea cross links N1 of deoxyguanosine to N3 of deoxycytidine on opposite strands of duplex DNA. Cancer Res 1999, 59:4363-4368.

36. Batista LF, Roos WP, Christmann M, Menck CF, Kaina B: Differential sensitivity of malignant glioma cells to methylating and chloroethylating anticancer drugs: p53 determines the switch by regulating $\mathrm{xpc}, \mathrm{ddb} 2$, and DNA double-strand breaks. Cancer Res 2007, 67:11886-11895.

37. McCord AM, Jamal M, Williams ES, Camphausen K, Tofilon PJ: CD133+ Glioblastoma Stem-like Cells are Radiosensitive with a Defective DNA Damage Response Compared with Established Cell Lines. Clinical Cancer Research 2009, 15:5145-5153.

38. Ropolo M, Daga A, Griffero F, Foresta M, Casartelli G, Zunino A, Poggi A, Cappelli E, Zona G, Spaziante R, Corte G, Frosina G: Comparative Analysis of DNA Repair in Stem and Nonstem Glioma Cell Cultures. Molecular Cancer Research 2009, 7:383-392.

39. Verhaak RG, Hoadley KA, Purdom E, Wang V, Qi Y, Wilkerson MD, Miller CR, Ding L, Golub T, Mesirov JP, Alexe G, Lawrence M, O'Kelly M, Tamayo P, Weir BA, Gabriel S, Winckler W, Gupta S, Jakkula L, Feiler HS, Hodgson JG, James CD, Sarkaria JN, Brennan C, Kahn A, Spellman PT, Wilson RK, Speed TP, Gray JW, Meyerson M, et al: Integrated Genomic Analysis Identifies Clinically Relevant Subtypes of Glioblastoma Characterized by Abnormalities in PDGFRA, IDH1, EGFR, and NF1. Cancer Cell 2010, 17:98-110.

40. Li A, Walling J, Kotliarov Y, Center A, Steed ME, Ahn SJ, Rosenblum M, Mikkelsen T, Zenklusen JC, Fine HA: Genomic Changes and Gene Expression Profiles Reveal That Established Glioma Cell Lines Are Poorly Representative of Primary Human Gliomas. Mol Cancer Res 2008, 6:21-30.

41. Lee J, Kotliarova S, Kotliarov Y, Li A, Su Q, Donin NM, Pastorino S, Purow BW, Christopher N, Zhang W, Park JK, Fine HA: Tumor stem cells derived from glioblastomas cultured in bFGF and EGF more closely mirror the phenotype and genotype of primary tumors than do serumcultured cell lines. Cancer Cell 2006, 9:391-403.

42. Kondo T, Setoguchi T, Taga T: Persistence of a small subpopulation of cancer stem-like cells in the C6 glioma cell line. Proc Natl Acad Sci USA 2004, 101:781-786.

43. Wu A, Oh S, Wiesner SM, Ericson K, Chen L, Hall WA, Champoux PE, Low WC, Ohlfest JR: Persistence of CD133+ cells in human and mouse glioma cell lines: detailed characterization of GL261 glioma cells with cancer stem cell-like properties. Stem Cells Dev 2008, 17:173-184.

44. Roos WP, Batista LF, Naumann SC, Wick W, Weller M, Menck CF, Kaina B: Apoptosis in malignant glioma cells triggered by the temozolomideinduced DNA lesion O6-methylguanine. Oncogene 2007, 26:186-197.

45. Hermisson M, Klumpp A, Wick W, Wischhusen J, Nagel G, Roos W, Kaina B, Weller M: O-methylguanine DNA methyltransferase and p53 status predict temozolomide sensitivity in human malignant glioma cells. $J$ Neurochem 2005

46. Combs SE, Schulz-Ertner D, Roth W, Herold-Mende C, Debus J, Weber KJ: In vitro responsiveness of glioma cell lines to multimodality treatment with radiotherapy, temozolomide, and epidermal growth factor receptor inhibition with cetuximab. Int J Radiat Oncol Biol Phys 2007, 68:873-882.

47. Bobola MS, Silber JR, Ellenbogen RG, Geyer JR, Blank A, Goff RD: O6methylguanine-DNA methyltransferase, O6-benzylguanine, and resistance to clinical alkylators in pediatric primary brain tumor cell lines. Clin Cancer Res 2005, 11:2747-2755.

48. Iwado E, Daido S, Kondo Y, Kondo S: Combined effect of 2-5A-linked antisense against telomerase RNA and conventional therapies on human malignant glioma cells in vitro and in vivo. Int J Oncol 2007 31:1087-1095

49. Ashley DM, Riffkin CD, Lovric MM, Mikeska T, Dobrovic A, Maxwell JA, Friedman HS, Drummond KJ, Kaye AH, Gan HK, Johns TG, Hawkins CJ: In vitro sensitivity testing of minimally passaged and uncultured gliomas with TRAIL and/or chemotherapy drugs. Br J Cancer 2008, 99:294-304.

50. Fomchenko El, Holland EC: Stem cells and brain cancer. Exp Cell Res 2005 , 306:323-329
51. Eramo A, Ricci-Vitiani L, Zeuner A, Pallini R, Lotti F, Sette G, Pilozzi E, Larocca LM, Peschle C, De Maria R: Chemotherapy resistance of glioblastoma stem cells. Cell Death Differ 2006, 13:1238-1241.

52. Clement V, Sanchez P, de Tribolet N, Radovanovic I, Ruiz i Altaba A: HEDGEHOG-GLI1 signaling regulates human glioma growth, cancer stem cell self-renewal, and tumorigenicity. Curr Biol 2007, 17:165-172.

53. Beier D, Rohrl S, Pillai DR, Schwarz S, Kunz-Schughart LA, Leukel P, Proescholdt M, Brawanski A, Bogdahn U, Trampe-Kieslich A, Giebel B, Wischhusen J, Reifenberger G, Hau P, Beier CP: Temozolomide preferentially depletes cancer stem cells in glioblastoma. Cancer Res 2008, 68:5706-5715.

54. Liu G, Yuan X, Zeng Z, Tunici P, Ng H, Abdulkadir IR, Lu L, Irvin D, Black KL, Yu JS: Analysis of gene expression and chemoresistance of CD133+ cancer stem cells in glioblastoma. Mol Cancer 2006, 5:67.

55. Ghods AJ, Irvin D, Liu G, Yuan X, Abdulkadir IR, Tunici P, Konda B, Wachsmann-Hogiu S, Black KL, Yu JS: Spheres isolated from $9 \mathrm{~L}$ gliosarcoma rat cell line possess chemoresistant and aggressive cancer stem-like cells. Stem Cells 2007, 25:1645-1653.

56. Chua C, Zaiden N, Chong KH, See SJ, Wong MC, Ang BT, Tang C: Characterization of a side population of astrocytoma cells in response to temozolomide. J Neurosurg 2008, 109:856-866.

57. Bleau AM, Hambardzumyan D, Ozawa T, Fomchenko El, Huse JT, Brennan CW, Holland EC: PTEN/PI3K/Akt pathway regulates the side population phenotype and $A B C G 2$ activity in glioma tumor stem-like cells. Cell Stem Cell 2009, 4:226-235.

58. Reynolds BA, Weiss S: Generation of neurons and astrocytes from isolated cells of the adult mammalian central nervous system. Science 1992, 255:1707-1710.

59. Blough MD, Westgate MR, Beauchamp D, Kelly JJ, Stechishin O, Ramirez AL, Weiss S, Cairncross JG: Sensitivity to temozolomide in brain tumor initiating cells. Neuro Oncol 2010.

60. Lamoral-Theys D, Le Mercier M, Le Calve B, Rynkowski MA, Bruyere C, Decaestecker C, Haibe-Kains B, Bontempi G, Dubois J, Lefranc F, Kiss R: Long-term temozolomide treatment induces marked amino metabolism modifications and an increase in TMZ sensitivity in $\mathrm{Hs} 683$ oligodendroglioma cells. Neoplasia 2010, 12:69-79.

61. Villalva C, Martin-Lanneree S, Cortes U, Dkhissi F, Wager M, Le Corf A, Tourani J, Dusanter-Fourt I, Turhan A, Karayan-Tapon L: STAT3 is essential for the maintenance of neurosphere-initiating tumor cells in patients with glioblastomas : A potential for targeted therapy ? Int J Cancer 2010, Epub.

62. Hsieh A, Ellsworth R, Hsieh D: Hedgehog/GLI1 regulates IGF dependent malignant behaviors in glioma stem cells. J Cell Physiol 2010, 226:1118-1127.

63. Mihaliak AM, Gilbert CA, Li L, Daou MC, Moser RP, Reeves A, Cochran BH, Ross $\mathrm{AH}$ : Clinically relevant doses of chemotherapy agents reversibly block formation of glioblastoma neurospheres. Cancer Lett 2010, 296:168-177.

64. Gilbert CA, Daou MC, Moser RP, Ross AH: Gamma-secretase inhibitors enhance temozolomide treatment of human gliomas by inhibiting neurosphere repopulation and xenograft recurrence. Cancer Res 2010, 70:6870-6879.

65. Pistollato F, Abbadi S, Rampazzo E, Persano L, Puppa AD, Frasson C, Sarto E, Scienza R, D'Avella D, Basso G: Intratumoral Hypoxic Gradient Drives Stem Cells Distribution and MGMT Expression in Glioblastoma. Stem Cells 2010, 28:851-862.

66. Glas M, Rath BH, Simon M, Reinartz R, Schramme A, Trageser D, Eisenreich R, Leinhaas A, Keller M, Schildhaus HU, Garbe S, Steinfarz B, Pietsch T, Steindler DA, Schramm J, Herrlinger U, Brüstle O, Scheffler B: Residual tumor cells are unique cellular targets in glioblastoma. Annals of Neurology 2010, 9999, NA..

67. Kang MK, Kang SK: Tumorigenesis of chemotherapeutic drug-resistant cancer stem-like cells in brain glioma. Stem Cells Dev 2007, 16:837-847.

68. Esteller M, Garcia-Foncillas J, Andion E, Goodman SN, Hidalgo OF, Vanaclocha V, Baylin SB, Herman JG: Inactivation of the DNA-Repair Gene MGMT and the Clinical Response of Gliomas to Alkylating Agents. N Engl J Med 2000, 343:1350-1354

69. Hegi ME, Diserens AC, Gorlia T, Hamou MF, de Tribolet N, Weller M, Kros JM, Hainfellner JA, Mason W, Mariani L, Bromberg JE, Hau P, Mirimanoff RO, Cairncross JG, Janzer RC, Stupp R: MGMT gene silencing 
and benefit from temozolomide in glioblastoma. N Engl J Med 2005, 352:997-1003.

70. Chinot OL, Barrie M, Fuentes S, Eudes N, Lancelot S, Metellus P, Muracciole X, Braguer D, Ouafik L, Martin PM, Dufour H, Figarella-Branger D: Correlation between 06-methylguanine-DNA methyltransferase and survival in inoperable newly diagnosed glioblastoma patients treated with neoadjuvant temozolomide. J Clin Oncol 2007, 25:1470-1475.

71. Martinez R, Schackert G, Yaya-Tur R, Rojas-Marcos I, Herman JG, Esteller M: Frequent hypermethylation of the DNA repair gene MGMT in long-term survivors of glioblastoma multiforme. J Neurooncol 2007, 83:91-93.

72. Bleau AM, Hambardzumyan D, Ozawa T, Fomchenko El, Huse JT, Brennan CW, Holland EC: PTEN/PI3K/Akt Pathway Regulates the Side Population Phenotype and ABCG2 Activity in Glioma Tumor Stem-like Cells. Cell Stem Cell 2009, 4:226-235.

73. Schaich M, Kestel L, Pfirmann M, Robel K, Illmer T, Kramer M, Dill C, Ehninger G, Schackert G, Krex D: A MDR1 (ABCB1) gene single nucleotide polymorphism predicts outcome of temozolomide treatment in glioblastoma patients. Ann Oncol 2009, 20:175-181.

74. Yip S, Miao J, Cahill DP, lafrate AJ, Aldape K, Nutt CL, Louis DN: MSH6 mutations arise in glioblastomas during temozolomide therapy and mediate temozolomide resistance. Clin Cancer Res 2009, 15:4622-4629.

75. Cahill DP, Levine KK, Betensky RA, Codd PJ, Romany CA, Reavie LB, Batchelor TT, Futreal PA, Stratton MR, Curry WT, lafrate AJ, Louis DN: Loss of the mismatch repair protein MSH6 in human glioblastomas is associated with tumor progression during temozolomide treatment. Clin Cancer Res 2007, 13:2038-2045.

76. Sarkaria JN, Kitange GJ, James CD, Plummer R, Calvert $H$, Weller M, Wick W: Mechanisms of Chemoresistance to Alkylating Agents in Malignant Glioma. Clinical Cancer Research 2008, 14:2900-2908.

77. Hirose Y, Berger MS, Pieper RO: Abrogation of the Chk1-mediated G(2) checkpoint pathway potentiates temozolomide-induced toxicity in a p53-independent manner in human glioblastoma cells. Cancer Res 2001, 61:5843-5849.

78. Hirose Y, Katayama M, Mirzoeva OK, Berger MS, Pieper RO: Akt activation suppresses Chk2-mediated, methylating agent-induced G2 arrest and protects from temozolomide-induced mitotic catastrophe and cellular senescence. Cancer Res 2005, 65:4861-4869.

79. Mhaidat NM, Zhang XD, Allen J, Avery-Kiejda KA, Scott RJ, Hersey P: Temozolomide induces senescence but not apoptosis in human melanoma cells. Br J Cancer 2007, 97:1225-1233.

80. Katayama M, Kawaguchi T, Berger MS, Pieper RO: DNA damaging agentinduced autophagy produces a cytoprotective adenosine triphosphate surge in malignant glioma cells. Cell Death Differ 2007, 14:548-558.

81. Kanzawa T, Germano IM, Komata T, Ito H, Kondo Y, Kondo S: Role of autophagy in temozolomide-induced cytotoxicity for malignant glioma cells. Cell Death Differ 2004, 11:448-457.

82. Das A, Banik NL, Patel SJ, Ray SK: Dexamethasone protected human glioblastoma U87MG cells from temozolomide induced apoptosis by maintaining Bax:Bcl-2 ratio and preventing proteolytic activities. $\mathrm{Mol}$ Cancer 2004, 3:36

83. Brada M, Judson I, Beale P, Moore S, Reidenberg P, Statkevich P, Dugan M, Batra V, Cutler D: Phase I dose-escalation and pharmacokinetic study of temozolomide (SCH 52365) for refractory or relapsing malignancies. Br J Cancer 1999, 81:1022-1030.

84. Rosso L, Brock CS, Gallo JM, Saleem A, Price PM, Turkheimer FE, Aboagye EO: A new model for prediction of drug distribution in tumor and normal tissues: pharmacokinetics of temozolomide in glioma patients. Cancer Res 2009, 69:120-127.

85. Ostermann S, Csajka C, Buclin T, Leyvraz S, Lejeune F, Decosterd LA, Stupp R: Plasma and cerebrospinal fluid population pharmacokinetics of temozolomide in malignant glioma patients. Clin Cancer Res 2004, 10:3728-3736.

86. Portnow J, Badie B, Chen M, Liu A, Blanchard S, Synold TW: The Neuropharmacokinetics of Temozolomide in Patients with Resectable Brain Tumors: Potential Implications for the Current Approach to Chemoradiation. Clin Cancer Res 2009.

87. Brandes AA, Tosoni A, Franceschi E, Sotti G, Frezza G, Amista P, Morandi L, Spagnolli F, Ermani M: Recurrence pattern after temozolomide concomitant with and adjuvant to radiotherapy in newly diagnosed patients with glioblastoma: correlation with MGMT promoter methylation status. J Clin Oncol 2009, 27:1275-1279.
88. Wick W, Stupp R, Beule AC, Bromberg J, Wick A, Ernemann U, Platten M, Marosi C, Mason WP, van den Bent M, Weller M, Rorden C, Karnath HO: A novel tool to analyze MRI recurrence patterns in glioblastoma. Neuro Oncol 2008, 10:1019-1024.

89. Meads MB, Hazlehurst LA, Dalton WS: The Bone Marrow Microenvironment as a Tumor Sanctuary and Contributor to Drug Resistance. Clin Cancer Res 2008, 14:2519-2526.

90. Murat A, Migliavacca E, Gorlia T, Lambiv WL, Shay T, Hamou MF, de Tribolet N, Regli L, Wick W, Kouwenhoven MC, Hainfellner JA, Heppner FL, Dietrich PY, Zimmer Y, Cairncross JG, Janzer RC, Domany E, Delorenzi M, Stupp R, Hegi ME: Stem cell-related "self-renewal" signature and high epidermal growth factor receptor expression associated with resistance to concomitant chemoradiotherapy in glioblastoma. J Clin Oncol 2008, 26:3015-3024.

91. Penuelas S, Anido J, Prieto-Sanchez RM, Folch G, Barba I, Cuartas I, GarciaDorado D, Poca MA, Sahuquillo J, Baselga J, Seoane J: TGF-beta increases glioma-initiating cell self-renewal through the induction of LIF in human glioblastoma. Cancer Cell 2009, 15:315-327.

92. Li Z, Bao S, Wu Q, Wang H, Eyler C, Sathornsumetee S, Shi Q, Cao Y, Lathia J, McLendon RE, Hjelmeland AB, Rich JN: Hypoxia-Inducible Factors Regulate Tumorigenic Capacity of Glioma Stem Cells. Cancer Cell 2009, 15:501-513.

93. McCord AM, Jamal M, Shankavaram UT, Lang FF, Camphausen K, Tofilon PJ: Physiologic oxygen concentration enhances the stem-like properties of CD133+ human glioblastoma cells in vitro. Mol Cancer Res 2009, 7:489-497.

94. Seidel S, Garvalov BK, Wirta V, von Stechow L, Schanzer A, Meletis K, Wolter M, Sommerlad D, Henze AT, Nister M, Reifenberger G, Lundeberg J, Frisen J, Acker T: A hypoxic niche regulates glioblastoma stem cells through hypoxia inducible factor 2 alpha. Brain 2010, 133:983-995.

95. Quintana E, Shackleton M, Sabel MS, Fullen DR, Johnson TM, Morrison SJ: Efficient tumour formation by single human melanoma cells. Nature 2008, 456:593-598.

doi:10.1186/1476-4598-10-128

Cite this article as: Beier et al:: Chemoresistance of glioblastoma cancer stem cells - much more complex than expected. Molecular Cancer 2011 10:128.

\section{Submit your next manuscript to BioMed Central and take full advantage of:}

- Convenient online submission

- Thorough peer review

- No space constraints or color figure charges

- Immediate publication on acceptance

- Inclusion in PubMed, CAS, Scopus and Google Scholar

- Research which is freely available for redistribution

Submit your manuscript at www.biomedcentral.com/submit
Ciomed Central 